\title{
PENGARUH PROMOSI DAN CITRA MEREK TERHADAP KEPUTUSAN PEMBELIAN ROKOK A MILD YANG DITAWARKAN OLEH PT DUTA MEDIA INDONESIA AREA PEMATANGSIANTAR
}

(Studi Kasus Pada Konsumen Warung Kopi H Pematangsiantar)

\author{
Oleh: \\ Dwita Suhari Yati Tarigan \\ S1 Manajemen \\ Darwin Lie, Efendi, Erbin Chandra
}

Abstraksi

Hasil penelitian ini dapat disimpulkan sebagai berikut: 1) Konsumen menyatakan bahwa promosi, citra merek dan keputusan pembelian rokok A Mild dikategorikan baik. 2) Hasil analisis regresi $\hat{Y}=15,181+0,297 X_{1}$ $+0,765 X_{2}$, artinya terdapat pengaruh yang positif antara promosi $\left(X_{1}\right)$ dan citra merek $\left(X_{2}\right)$ terhadap keputusan pembelian (Y) rokok A Mild yang ditawarkan oleh PT Duta Media Indonesia Area Pematangsiantar. 3) Nilai korelasi $\mathrm{r}=0,653$ yang artinya terdapat hubungan yang kuat dan positif antara promosi, citra merek dan keputusan pembelian rokok A Mild yang ditawarkan oleh PT Duta Media Indonesia Area Pematangsiantar. Nilai koefisien determinasi yaitu 0,427 , artinya kuat tidaknya keputusan pembelian dijelaskan sebesar $42,7 \%$ oleh promosi dan citra merek. 4) Hipotesis $\mathrm{H}_{\mathrm{o}}$ ditolak, artinya promosi dan citra merek berpengaruh positif dan signifikan terhadap keputusan pembelian rokok A Mild yang ditawarkan oleh PT Duta Media Indonesia Area Pematangsiantar.

Adapun saran dari hasil penelitian menyimpulkan bahwa rokok A Mild yang ditawarkan oleh PT Duta Media Indonesia Area Pematangsiantar dalam pengaruh keputusan pembelian, maka perusahaan harus meningkatkan dan memperbaiki promosi dan citra merek rokok A Mild. Semakin baik promosi dan citra merek rokok A Mild, maka akan meningkatkan keputusan pembelian rokok A Mild.

Kata Kunci : Promosi, Citra Merek dan Keputusan Pembelian.

\section{Abstraction}

The results of this study can be summarized as follows: 1) Consumers declare that promotion, brand image and purchase decisions A Mild cigarettes are categorized well. 2) Regression analysis result $\hat{Y}=15,181+$ $0,297 X 1+0,765 X 2$, meaning there is positive influence between promotion (X1) and brand image (X2) to decision of purchase (Y) A Mild cigarettes offered by PT Duta Media Indonesia Pematangsiantar Area. 3) Correlation value $r=0,653$ which means there is moderately high and positive correlation between promotion, brand image and purchase decision of A Mild cigarettes offered by PT Duta Media Indonesia Pematangsiantar Area. The coefficient of determination is 0,427, meaning that the strongness of purchasing decision is explained by $42,7 \%$ by promotion and brand image. 4) Hypothesis Ho rejected, meaning promotion and brand image has a positive and significant effect on the decision of A Mild cigarette purchase offered by PT Duta Media Indonesia Pematangsiantar Area.

The suggestion from the research result concludes that A Mild cigarettes offered by PT Duta Media Indonesia Pematangsiantar Area in the influence of purchasing decision, hence company must improve and improve promotion and image of A Mild cigarette brand. The better promotion and brand image of A Mild cigarettes, it will improve the purchase decision of A Mild cigarettes.

Keywords: Promotion, Brand Image and Purchase Decision.

\section{A. PENDAhuluan}

\section{Latar Belakang Masalah}

PT Duta Media Indonesia Area

Pematangsiantar adalah salah satu perusahaan jasa yang bergerak di bidang promosi agency PT HM Sampoerna. PT Duta Media Indonesia Area Pematangsiantar harus selalu berinovasi dan kreatif dengan tujuan mampu menarik minat beli konsumen karena pembelian konsumen yang terjadi merupakan sumber penghasilan perusahaan.

Adapun jenis rokok yang dihasilkan PT HM Sampoerna kepada PT Duta Media Indonesia Area Pematangsiantar adalah Rokok A Mild, U Mild, Sampoerna Kretek, dan Dji Sam Soe. Dalam penelitian ini penulis tertarik untuk memilih produk Rokok A Mild karena banyak konsumen yang minat atas produk rokok tersebut, sehingga lebih mempermudah peneliti untuk menentukan sampel penelitian.

Keputusan pembelian konsumen menjadi faktor yang penting dalam penentu eksistensi suatu perusahaan. Suatu perusahaan dapat terus eksis jika rangsangan konsumen dalam memutuskan pembelian produk dari suatu pasar mendapat respon yang positif dari pasar itu sendiri. Dimensi keputusan pembelian meliputi pengenalan masalah, evaluasi alternatif, keputusan pembelian dan perilaku setelah pembelian.

Salah satu faktor yang mempengaruhi keputusan pembelian Rokok A Mild adalah kegiatan promosi. PT Duta Media Indonesia Area Pematangsiantar melakukan kegiatan promosi untuk 
mengkomunikasikan kualitas, rasa dan harga Rokok A Mild terhadap konsumen. Apabila promosi yang diberikan sesuai dan dapat diterima oleh konsumen, maka konsumen memutuskan untuk membeli produk tersebut. Dalam mempertahankan dan meningkatkan promosinya berbagai upaya yang dilakukan dengan menggunakan alat promosi antara lain periklanan (advertising) meliputi brosur, spanduk, t-shirt, hubungan masyarakat (public relations), penjualan personal (personal selling) dan pemasaran langsung (direct marketing).

Faktor lain yang mempengaruhi keputusan pembelian adalah citra merek (Brand Image). Merek mempunyai sifat khas, dan sifat khas ini yang membedakan satu merek dengan merek lainnya. Adapun dimensi citra merek meliputi keunggulan merek, kekuatan merek dan keunikan merek.

\section{Rumusan Masalah}

a. Bagaimana gambaran promosi, citra merek dan keputusan pembelian rokok A Mild yang ditawarkan oleh PT Duta Media Indonesia Area Pematangsiantar.

b. Bagaimana pengaruh promosi dan citra merek terhadap keputusan pembelian rokok A Mild yang ditawarkan oleh PT Duta Media Indonesia Area Pematangsiantar baik secara simultan maupun parsial.

\section{Tujuan Penelitian}

a. Untuk mengetahui gambaran promosi, citra merek dan keputusan pembelian rokok A Mild yang ditawarkan oleh PT Duta Media Indonesia Area Pematangsiantar.

b. Untuk mengetahui pengaruh promosi dan citra merek terhadap keputusan pembelian rokok A Mild yang ditawarkan oleh PT Duta Media Indonesia Area Pematangsiantar baik secara simultan maupun parsial.

\section{Metode Penelitian}

Objek penelitian dalam hal ini adalah konsumen Rokok A Mild di Warung Kopi H Pematangsiantar yang terletak di jalan Kartini No. 46, kelurahan Banjar, kecamatan Siantar Barat, kota Pematangsiantar, Sumatera Utara. Nomor Telepon (0622) 7354237. Populasi adalah konsumen Rokok A Mild di Warung Kopi H Pematangsiantar yang berjumlah 360 (tiga ratus enam puluh) orang di hari weekend (Sabtu-Minggu) pada bulan juli tahun 2017. Setelah dihitung dengan rumus Slovin, maka sampel adalah 189 orang.

Desain penelitian adalah Penelitian Kepustakaan (Library Research) dan Penelitian Lapangan (Field Research). Teknik pengumpulan data berupa Kuesioner, Wawancara dan Dokumentasi. Jenis data yang adalah jenis data kualitatif dan data kuantitatif. Hasil data yang diperoleh dari lapangan akan dianalisis secara deskriptif baik bersifat kualitatif dan kuantitatif.

\section{B. LANDASAN TEORI}

1. Manajemen Pemasaran
Menurut Lupiyoadi dan Hamdani (2006:6), manajemen pemasaran merupakan bentuk hubungan dengan pertukaran-pertukaran yang diinginkan terhadap konsumen yang dituju untuk memperoleh keruntungan pribadi maupun bersama melalui suatu analisis, perencanaan, pelaksanaan, serta kontrol program-program yang telah direncanakan. Sedangkan menurut Boyd, et. al. (2000:18), manajemen pemasaran (marketing management) merupakan proses menganalisis, merencanakan, mengkoordinasikan dan mengendalikan programprogram yang mencakup pengkonsepan, menetapkan harga, promosi dan distribusi dari produk, jasa dan gagasan yang dirancang untuk menciptakan dan memelihara pertukaran yang menguntungkan dengan pasar sasaran untuk mencapai tujuan perusahaan.Sedangkan menurut Kotler dan Kevin (2009:5), manajemen pemasaran adalah seni dan ilmu memilih pasar sasaran dan meraih, mempertahankan, serta menumbuhkan pelaggan dengan menciptakan, menghantarkan dan mengkomunikasikan nilai pelanggan yang unggul.

Dari beberapa definisi di atas, maka dapat disimpulkan bahwa manajemen pemasaran adalah proses merencanakan, penganalisaan, pelaksanaan, mengimplementasikan dan pengawasan atau mengendalikan kegiatan pemasaran dalam suatu perusahaan agar tercapainya target atau tujuan perusahaan secara lebih efisien dan efektif.

\section{Promosi}

Menurut Tjiptono dan Gregorius (2011:219), promosi didefinisikan sebagai suatu proses komunikasi pemasaran, maksudnya berupa aktifitas pemasaran yang berusaha menyebarkan informasi, mempengaruhi, membujuk, dan mengingatkan pasar sasaran atas perusahaan dan produknya agar bersedia mendapatkan, membeli, dan setia pada produk yang ditawarkan oleh perusahaan yang bersangkutan.

Sedangkan menurut Boyd, et. al (2000:65), promosi adalah upaya membujuk orang untuk menerima produk, konsep dan gagasan. Lalu menurut Swastha dan Irawan (2005:15), promosi didefinisikan sebagai suatu sistem yang bertujuan untuk merencanakan, menentukan harga, mempromosikan, dan mendistribusikan barang dan jasa untuk memuaskan kebutuhan baik kepada pembeli yang ada maupun pembeli yang potensial dari keseluruhan dari kegiatan-kegiatan bisnis yang dilakukan oleh perusahaan.

Dari uraian diatas dapat diambil kesimpulan bahwa promosi merupakan kegiatan dalam bentuk komunikasi atau pemberi informasi mengenai suatu produk kepada konsumen, agar konsumen yang bersangkutan menggunakan produk tersebut untuk memenuhi kebutuhannya.

\section{Citra Merek}

\section{Menurut Ferrinadewi (2008:165),} berpendapat bahwa brand image adalah persepsi tentang merek yang merupakan refleksi memori konsumen akan asosiasinya pada merek tersebut. 
Dapat juga dikatakan bahwa brand image merupakan konsep yang dibuat oleh pelanggan karena alasan subyektif dan emosi pribadinya terhadap suatu produk. Oleh karena itu dalam konsep ini persepsi konsumen ini persepsi konsumen menjadi lebih penting daripada keadaan sesungguhnya.

Menurut Setiadi (2003:180), berpendapat citra merek mengacu pada skema memori akan sebuah merek, yang berisikan interpretasi konsumen atas atribut, kelebihan, penggunaan, situasi, pada pengguna dan karakteristik pemasar dan/atau karakteristik pembuat dari produk/merek tersebut. Citra merek adalah apa yang konsumen pikirkan dan rasakan ketika mendengar atau melihat nama suatu merek. Sedangkan menurut Kotler dan Kevin (2008:332), citra merek adalah suatu kesan yang ada dalam benak konsumen mengenai suatu merek yang hal ini dibentuk oleh pesan dan pengalaman konsumen mengenai merek, sehingga menimbulkan citra yang ada dibenak konsumen.

Menurut beberapa defenisi para ahli dapat disimpulkan bahwa citra merek (brand image), mengacu pada skema memori akan sebuah merek, yang berisikan interpretasi konsumen atas atribut, kelebihan, penggunaan, situasi, para pengguna, dan karakteristik pemasar dan/atau karakteristik pembuat dari produk/merek tersebut serta representasi dari keseluruhan persepsi terhadap merek dan dibentuk dari informasi dan pengalaman masa lalu terhadap merek itu.

\section{Keputusan Pembelian}

Menurut Setiadi (2010:332), keputusan pembelian adalah proses pengintegrasian yang mengkombinasikan pengetahuan untuk mengevaluasi dua perilaku alternatif atau lebih dan memilih salah satu di antaranya. Menurut Kotler dan Kevin (2009:188), keputusan pembelian adalah proses dimana konsumen membentuk preferensi antar merek dalam kumpulan pilihan atau konsumen mungkin juga membentuk maksud untuk membeli merek yang poling disukai. Sedangkan menurut Kotler dan Gary (2008:181), keputusan pembelian adalah membeli merek yang paling di sukai, tetapi dua faktor bisa berada antara antara niat pembelian dan keputusan pembelian. Para konsumen membutuhkan cara untuk melepaskan ketegangan yang terjadi atau melepaskan sesuatu yang sudah terjadi karena mereka membutuhkan pelepasan ketegangan.

Dari pengertian para ahli diatas, dapat diambil kesimpulan bahwa keputusan pembelian merupakan tindakan yang dilakukan konsumen untuk membeli suatu produk, dimana pada dasarnya pengambilan keputusan pembelian setiap orang sama, dalam proses dalam pengambilan keputusan pembelian pasti berbeda-beda, seperti kepribadian, gaya hidup, usia, penghasilan dan lain-lain.

5.Pengaruh Promosi dan Citra Merek terhadap Keputusan Pembelian

Pengaruh promosi terhadap keputusan pembelian sangatlah penting, karena dengan promosi dapat mengenalkan produk-produk perusahaan yang akan ditawarkan kepada pelanggan dan mempengaruhi persepsi konsumen akan produk itu sendiri.

Promosi adalah suatu kegiatan yang penting di suatu perusahaan. Menurut Boyd, et. al (2000:65), promosi adalah upaya membujuk orang untuk menerima produk, konsep dan gagasan. Selain itu memberikan souvenir saat promosi penjualan dan melakukan kegiatan yang melibatkan masyarakat akan menarik minat konsumen, sehingga memberikan rasa puas karena pelanggan merasa diberi sesuatu yang berbeda. Dengan begitu pelanggan menjadi bertambah sehingga meningkatkan keuntungan yang di dapat perusahaan.

Menurut Kotler dan Gary (2008:181), konsumen mementingkan citra merek dalam membentuk niat pembelian. Citra merek (brand image) yang dikelola dengan baik akan menghasilkan konsekuensi yang positif, seperti meningkatkan pemahaman terhadap aspek-aspek perilaku konsumen dalam mengambil keputusan pembelian konsumen, memperkaya orientasi konsumsi terhadap hal-hal yang bersifat simbolis lebih dari fungsi-fungsi produk, meningkatkan keunggulan bersaing berkelanjutan mengingat inovasi teknologi sangat muda untuk ditiru oleh pesaing. Dengan adanya keunggulan bersaing yang berkelanjutan, maka pesaing-pesaing akan kesulitan dalam memenangkan pesaingnya.

Jadi menurut pendapat para ahli diatas, maka dapat disimpulkan bahwa promosi dan citra merek merupakan suatu kombinasi untuk mendukung keputusan pembelian, dan hubungan positif antara promosi dan citra merek diperlukan agar dapat merangsang keinginan konsumen untuk membelinya sehingga dapat meningkatkan keputusan pembelian konsumen dan akan berdampak pada peningkatan penjualan perusahaan.

\section{PEMBAHASAN}

\section{Analisa}

\section{a. Deskriptif Kualitatif}

Analisis deskriptif dimaksudkan untuk mendapatkan gambaran atau deskripsi mengenai tanggapan dari konsumen mengenai Pengaruh Promosi dan Citra Merek terhadap Keputusan Konsumen rokok A Mild yang ditawarkan oleh PT Duta Media Indonesia Area Pematangsiantar. Setelah pengujian data, maka langkah selanjutnya peneliti melakukan pengkajian analisis kualitatif sebagai gambaran fenomena dari variabel penelitian pada saat sekarang ini.

Adapun penetapan kriteria nilai rata-rata jawaban dari responden tersebut dimasukkan ke dalam kelas-kelas interval dimana penentuan intervalnya memakai rumus sebagai berikut: Interval Kelas $=$ Nilai Tertinggi - Nilai Terendah

$$
\begin{aligned}
& =\frac{5-1}{5} \\
& =\frac{4}{5}
\end{aligned}
$$


$=0,8$

Dari rumus diatas dapat diperoleh interval kelas 0,8 sehingga berlaku ketentuan kategori dengan hasil berikut:

Tabel 1

Nilai Interval dan Kategori Jawaban Responden.

\begin{tabular}{|c|c|}
\hline Nilai Interval & Kategori Pertanyaan \\
\hline $4,21-5,00$ & Sangat Baik \\
\hline $3,41-4,20$ & Baik \\
\hline $2,61-3,40$ & Cukup Baik \\
\hline $1,81-2,60$ & Tidak Baik \\
\hline $1,00-1,80$ & Sangat Tidak Baik \\
\hline
\end{tabular}

Sumber : hasil pengolahan data

\section{1) Gambaran Promosi rokok A Mild yang ditawarkan oleh PT Duta Media Indonesia Area Pematangsintar}

Dari hasil analisa, dapat dilihat bahwa untuk dimensi kinerja (performances) pada pada indikator kejelasan informasi rokok A Mild melalui brosur diperoleh nilai rata-rata sebesar 4,05 dengan kriteria jawaban baik, hal ini karena informasi yang diperoleh konsumen melalui brosur sudah tepat dan jelas. Untuk indikator kejelasan informasi rokok A Mild melalui billboard diperoleh nilai rata-rata sebesar 3,97 dengan kriteria jawaban baik, hal ini karena informasi yang diterima konsumen sudah jelas melalui billboard walaupun pada dimensi periklanan indikator ini memiliki nilai terendah dibandingkan indikator lain. Sedangkan untuk indikator kejelasan informasi rokok A Mild melalui televisi diperoleh nilai rata-rata sebesar 4,05 dengan kriteria jawaban baik, hal ini karena informasi yang diperoleh oleh konsumen melalui televisi sudah tepat dan jelas.

Selanjutnya untuk jawaban atas dimensi hubungan masyarakat pada indikator acara yang diselenggarakan oleh rokok A Mild diperoleh nilai rata-rata sebesar 4,05 dengan kriteria jawaban baik, hal ini karena acara atau event yang diselenggarakan rokok A Mild sudah baik di mata konsumen dan masyarakat. Untuk indikaktor sponsor-sponsor yang diberikan rokok A Mild diperoleh nilai rata-rata sebesar 3,98 dengan kriteria jawaban baik, hal ini karena sponsor-sponsor yang diadakan rokok A Mild sudah membantu dan mensupport acara yang disponsori. Sedangkan indikator souvenir yang diberikan oleh rokok A Mild diperoleh nilai rata-rata sebesar 3,96 dengan kriteria jawaban baik, hal ini karena souvenir yang diberikan rokok A Mild sudah baik dan tepat kepada konsumen.

Dimensi penjualan personal pada indikator komunikasi brand presenter saat menawarkan rokok A Mild diperoleh nilai rata-rata sebesar 3,32 dengan kriteria jawaban cukup baik, hal ini disebabkan kurangnya komunikasi brand presenter kepada konsumen saat menawarkan rokok A Mild karena brand presenter memiliki waktu yang terbatas saat melakukan penjualan door to door. Untuk indikator kesopanan brand presenter saat menawarkan rokok A Mild diperoleh nilai rata-rata sebesar 3,83 dengan dengan kriteria jawaban baik, hal ini karena brand presenter saat menawarkan produk rokok A Mild berupaya melayani dengan sopan kepada konsumen. Sedangkan pada indikator presentasi saat menawarkan rokok A Mild diperoleh nilai rata-rata sebesar 3,29 dengan kriteria jawaban cukup baik, hal ini karena ada beberapa brand presenter masih kurang terlatih dalam presentasi tentang rokok A Mild.

Terakhir adalah dimensi pemasaran langsung pada indikator cara brand presenter dalam memberitahu keunggulan rokok A Mild dengan nilai rata-rata sebesar 3,92 dengan kriteria jawaban baik, hal ini karena brand presenter rokok A Mild telah tepat dan jelas dalam mengetahui keunggulan produk rokok A Mild. Untuk indikator keahlian brand presenter dalam membujuk untuk membeli rokok A Mild dengan nilai rata-rata sebesar 3,79 dengan kriteria jawaban baik, hal ini karena brand presenter sudah baik dalam membujuk konsumen untuk membeli produk yang mereka tawarkan. Sedangkan indikator cara brand presenter mengingatkan untuk tetap setia dalam mengkonsumsi rokok A Mild dengan nilai rata-rata sebesar 3,90 dengan kriteria jawaban baik, hal ini karena komunikasi brand presenter yang baik dan cara mengingatkan kepada konsumen juga baik .

Secara keseluruhan promosi diperoleh nilai rata-rata 3,84 dengan kriteria jawaban baik. Untuk nilai tertinggi diperoleh nilai rata-rata 4,05 dengan kriteria jawaban baik pada dimensi periklanan (advertising). Sedangkan untuk nilai terendah yaitu diperoleh nilai rata-rata sebesar 3,29 yaitu dengan kriteria jawaban cukup baik pada indikator presentasi brand presenter dalam menawarkan rokok A Mild dan indikator komunikasi brand presenter dalam menawarkan rokok A Mild diperoleh nilai sebesar 3,31 .

2) Gambaran Citra Merek rokok A Mild yang ditawarkan oleh PT Duta Media Indonesia Area Pematangsintar

Dari hasil analisa, dapat dilihat bahwa untuk dimensi keunggulan produk pada indikator kualitas pada produk rokok A Mild diperoleh nilai rata-rata sebesar 3,64 dengan kriteria jawaban baik, hal ini karena kualitas rokok A Mild sudah tepat dan baik dimata konsumen. Indikator ciri khas pada produk rokok A Mild diperoleh nilai rata-rata sebesar 3,57 dengan kriteria jawaban baik, hal ini karena ciri khas pada rokok A Mild sudah baik dimata konsumen. Dan pada indikator daya tarik pada produk rokok A Mild diperoleh nilai rata-rata sebesar 3,81 dengan kriteria jawaban baik, hal ini karena daya tarik yang dimiliki rokok A Mild sudah tepat dan baik bagi konsumen.

Dimensi kekuatan merek yaitu pada indikator rasa rokok A Mild diperoleh nilai rata-rata sebesar 3,86 dengan kriteria jawaban baik, hal ini karena rasa rokok A Mild disukai oleh konsumen. Indikator periklanan rokok A Mild diperoleh nilai rata-rata sebesar 3,84 dengan kriteria jawaban baik, hal ini karena periklanan yang diterapkan pada rokok A Mild sudah jelas dan baik bagi konsumen. Dan pada indikator daya tarik rokok A Mild diperoleh 
nilai rata-rata sebesar 3,75 dengan kriteria jawaban baik, hal ini karena rokok A Mild sudah baik dan memiliki daya tarik tersendiri bagi konsumen.

Terakhir dimensi keunikan merek yaitu pada indikator desain produk rokok A Mild diperoleh nilai rata-rata sebesar 3,71 dengan kriteria jawaban baik, hal ini karena desain produk rokok A Mild sudah baik dan menarik bagi konsumen. Indikator nama merek rokok A Mild diperoleh nilai rata-rata sebesar 3,61 dengan kriteria jawaban baik, hal ini karena nama merek rokok A Mild sudah banyak dikenal oleh masyarakat Indonesia. Sedangkan indikator logo merek rokok A Mild diperoleh nilai rata-rata sebesar 3,67 dengan kriteria jawaban baik, hal ini karena logo pada rokok A Mild sudah bagus dan memiliki logo yang unik.

Secara keseluruhan citra merek diperoleh nilai rata-rata sebesar 3,72 dengan kriteria jawaban baik. Untuk nilai tertinggi yaitu diperoleh nilai rata-rata sebesar 3,75 pada dimensi kekuatan merek dengan kriteria baik pada indikator daya ingat pada produk rokok A Mild. Sedangkan untuk nilai terendah yaitu diperoleh nilai rata-rata sebesar 3,57 yaitu dengan kriteria baik pada indikator ciri khas produk rokok A Mild.

\section{3) Gambaran Keputusan pembelian rokok A Mild yang ditawarkan oleh PT Duta Media Indonesia Area Pematangsintar}

Dari hasil analisa, dapat dilihat bahwa untuk dimensi dimensi pengenalan masalah pada indikator kebutuhan pada produk rokok A Mild diperoleh nilai rata-rata sebesar 3,68 dengan kriteria jawaban baik, hal ini karena rokok A Mild sudah sesuai dengan kebutuhan konsumen. Indikator kemudahan prosedur pembelian diperoleh nilai ratarata sebesar 3,70 dengan kriteria jawaban baik, hal ini karena rokok A Mild mudah didapatkan di warung terdekat. Dan pada indikator cara brand presenter mengenalkan produk diperoleh nilai ratarata sebesar 3,72 dengan kriteria jawaban baik, hal ini karena brand presenter sudah mampu memperkenalkan rokok A Mild dengan baik.

Dimensi pencarian informasi pada indikator kemudahan informasi yang didapatkan pada rokok A Mild diperoleh nilai rata-rata sebesar 3,92 dengan kriteria jawaban baik, hal ini karena informasi rokok A Mild yang didapatkan konsumen mudah. Indikator cara brand presenter mengenalkan produk rokok A Mild diperoleh nilai rata-rata sebesar 3,55 dengan kriteria jawaban baik, hal ini karena brand presenter sudah baik dan jelas dalam mengenalkan produk rokok A Mild kepada konsumen. Dan pada indikator keakuratan informasi rokok A Mild diperoleh nilai rata-rata sebesar 3,93 dengan kriteria jawaban baik, hal ini karena informasi rokok A Mild kepada konsumen sudah akurat.

Dimensi evaluasi alternatif pada indikator kemampuan rokok A Mild dalam memenuhi kebutuhan konsumen diperoleh nilai rata-rata sebesar 3,75 dengan kriteria jawaban baik, hal ini karena rokok A Mild sudah mampu memenuhi kebutuhan konsumen baik dari rasa dan kinerja produk.
Selanjutnya indikator manfaat rokok A Mild diperoleh nilai rata-rata sebesar 3,65 dengan kriteria jawaban baik, hal ini karena manfaat rokok A Mild yang dirasakan konsumen sudah baik dan sesuai. Dan pada indikator keyakinan dalam mengkonsumsi rokok A Mild diperoleh nilai rata-rata sebesar 3,57 dengan kriteria jawaban baik, hal ini menunjukkan bahwa konsumen sudah yakin dalam memilih rokok A Mild.

Dimensi keputusan pembelian pada indikator kesesuaian rasa pada produk rokok A Mild diperoleh nilai rata-rata sebesar 3,64 dengan kriteria jawaban baik, hal ini disebabkan karena konsumen sudah merasa sesuai pada rasa rokok A Mild. Indikator sikap membeli produk rokok A Mild diperoleh nilai rata-rata sebesar 3,74 dengan kriteria jawaban baik, hal ini karena sebagian besar konsumen merasa tertarik pada rokok A Mild. Dan pada indikator minat pada produk rokok A Mild diperoleh nilai rata-rata sebesar 3,19 dengan kriteria jawaban cukup baik, hal ini karena ada produk rokok lain yang menyebabkan minat beberapa konsumen kepada rokok A Mild tidak terlalu baik.

Terakhir dimensi perilaku setelah pembelian pada indikator kesesuaian kinerja rokok A Mild diperoleh nilai rata-rata sebesar 3,55 dengan kriteria jawaban baik, hal ini dikarenakan konsumen merasa kinerja rokok A Mild sudah sesuai. Indikator kepuasan mengkonsumsi produk rokok A Mild diperoleh nilai rata-rata sebesar 3,75 dengan kriteria jawaban baik, hal ini dikarenakan rata-rata konsumen merasa puas dalam mengkonsumsi rokok A Mild. Dan pada indikator sikap melakukan pembelian kembali rokok A Mild diperoleh nilai rata-rata sebesar 3,14 dengan kriteria jawaban cukup baik, Hal ini dikarenakan banyaknya variasi produk rokok yang beredar sehingga konsumen tidak selalu membeli kembali rokok A Mild.

Secara keseluruhan keputusan pembelian diperoleh nilai rata-rata sebesar 3,63 dengan kriteria jawaban baik. Untuk nilai tertinggi yaitu pada dimensi pencarian informasi diperoleh nilai rata-rata sebesar 3,93 dengan kriteria jawaban baik pada sub indikator keakuratan informasi pada rokok A Mild. Sedangkan untuk nilai terendah yaitu pada dimensi perilaku setelah pembelian diperoleh nilai rata-rata sebesar 3,14 dengan kriteria cukup baik pada sub indikator sikap melakukan pembelian kembali rokok A Mild.

\section{b. Deskriptif Kuantitatif}

\section{1) Regresi Linear Berganda}

Penelitian ini memiliki tujuan untuk menganalisis pengaruh promosi dan citra merek terhadap keputusan pembelian. Analisis data dalam penelitian ini menggunakan analisis regresi linier berganda. Analisis regresi linier berganda digunakan untuk mengetahui pengaruh variabel bebas (X) dan variabel terikat $(\mathrm{Y})$, dimana $\mathrm{X}$ adalah kualitas promosi, citra merek, dan $\mathrm{Y}$ adalah keputusan pembelian. Maka dilakukan perhitungan menggunakan program aplikasi SPSS versi 23 dengan hasil hitung regresi sebagai berikut: 
Tabel 2

Hasil Regresi Linier Berganda Coefficients $^{\mathrm{a}}$

\begin{tabular}{|c|c|c|c|c|}
\hline \multirow{2}{*}{\multicolumn{2}{|c|}{ Model }} & \multicolumn{2}{|c|}{$\begin{array}{l}\text { Unstandardize } \\
\text { d Coefficients }\end{array}$} & \multirow{2}{*}{$\begin{array}{c}\begin{array}{c}\text { Standardized } \\
\text { Coefficients }\end{array} \\
\text { Beta }\end{array}$} \\
\hline & & $\bar{B}$ & $\begin{array}{c}\text { Std. } \\
\text { Error }\end{array}$ & \\
\hline \multirow{3}{*}{1} & (Constant & 15.181 & 3.406 & \\
\hline & $\begin{array}{l}\text { PROMOS } \\
\text { I }\end{array}$ & .297 & .073 & .261 \\
\hline & $\begin{array}{l}\text { CITRA_M } \\
\text { EREK }\end{array}$ & .765 & .102 & .481 \\
\hline
\end{tabular}

a. Dependent Variable: KEP PEMBELIAN

Sumber: data primer hasil pengolahan SPSS Versi 23 tahun 2017.

Berdasarkan hasil pengolahan data pada tabel 2 di atas diperoleh model persamaan $\hat{\mathrm{Y}}=$ $15,181+0,297 \mathrm{X}_{1}+0,765 \mathrm{X}_{2}$, artinya terdapat pengaruh yang positif antara promosi dan citra merek terhadap keputusan pembelian rokok A Mild yang ditawarkan oleh PT Duta Media Indonesia Area Pematangsiantar.

2) Koefisien Korelasi dan Koefisien Determinasi

Hasil koefisien korelasi dan koefisien determinasi dapat dilihat pada tabel berikut:

Tabel 3

Hasil Koefisien Korelasi dan Determinasi Model Summary ${ }^{b}$

\begin{tabular}{|c|c|c|c|c|}
\hline Model & $\boldsymbol{R}$ & $\begin{array}{c}R \\
\text { Squar } \\
e\end{array}$ & $\begin{array}{c}\text { Adjuste } \\
\text { d } R \\
\text { Square }\end{array}$ & $\begin{array}{l}\text { Std. Error of } \\
\text { the Estimate }\end{array}$ \\
\hline 1 & $.653^{a}$ & .427 & .421 & 5.249 \\
\hline
\end{tabular}

a. Predictors: (Constant), CITRA_MEREK, PROMOSI

b. Dependent Variable: KEP_PEMBELIAN

Sumber: data primer hasil pengolahan SPSS Versi 23 tahun 2017.

a. Predictors: (Constant), citra merek, promosi

b. Dependent Variabel: keputusan pembelian

Sumber: hasil pengolahan data dengan SPSS versi 23

Berdasarkan tabel 3 diperoleh nilai $r=0,653$

yang artinya terdapat hubungan yang kuat dan positif antara promosi dan citra merek dengan keputusan pembelian rokok A Mild yang ditawarkan oleh PT Duta Media Indonesia Area Pematangsiantar, sesuai dengan kriteria koefisien korelasi pada tabel 5 . Kemudian diperoleh nilai koefisien determinasi yaitu 0,427 , artinya baik tidaknya keputusan pembelian dijelaskan sebesar $42,7 \%$ oleh promosi dan citra merek selebihnya $57,3 \%$ dijelaskan oleh faktor lain seperti situasional, lingkungan dan sosial budaya konsumen yang tidak dibahas dalam penelitian ini.

\section{3) Uji Hipotesis}

\section{a) Uji Simultan (Uji F)}

Pengujian ini dilakukan secara simultan, yaitu dilakukan untuk menentukan diterima atau ditolaknya hipotesis. Pengujian hipotesis dilakukan untuk mengetahui apakah variabel promosi dan citra merek yang diuji berpengaruh terhadap keputusan pembelian. Jika $F_{\text {hitung }}>F_{\text {tabel }}$ atau signifikansi $\leq$ 0,05 , maka $\mathrm{H}_{0}$ ditolak.

Untuk menghasilkan suatu kesimpulan yang valid, maka harus dilakukan uji hipotesis dengan menggunakan program SPSS versi 20.

Tabel 4

Hasil Uji Simultan (Uji F)

ANOVA ${ }^{\mathrm{a}}$

\begin{tabular}{|l|r|r|r|l|l|}
\hline Model & $\begin{array}{c}\text { Sum of } \\
\text { Squares }\end{array}$ & Df & $\begin{array}{c}\text { Mean } \\
\text { Square }\end{array}$ & $\boldsymbol{F}$ & Sig. \\
\hline Regres & 3818.10 & 2 & 1909.05 & $\mathbf{6 9 . 2 8 4}$ & $.000^{\mathrm{b}}$ \\
sion & 8 & & 4 & & \\
Residu & 5125.03 & 18 & 27.554 & & \\
al & 5 & 6 & & & \\
Total & 8943.14 & 18 & & & \\
3 & 8 & & & \\
\hline
\end{tabular}

a. Dependent Variable: KEP_PEMBELIAN b. Predictors: (Constant), CITRA MEREK, PROMOSI

Sumber: data primer hasil pengolahan SPSS Versi 23 tahun 2017.

a. Dependent Variabel: Keputusan Pembelian

b. Predictors: (Constant), Citra Merek, Promosi Sumber: hasil pengolahan data dengan SPSS versi 23 Berdasarkan tabel 4 di atas, diperoleh nilai $F_{\text {hitung }}$ sebesar 69,284 $>F_{\text {tabel }}$ pada tingkat $(0,05,2$ vs (186) adalah sebesar 3,04. Oleh karena $F_{\text {hitung }}>F_{\text {tabel }}$ atau taraf signifikansi $0,000<$ dari $\alpha 0,05$ maka $H_{o}$ ditolak, artinya promosi dan citra merek berpengaruh positif dan signifikan terhadap keputusan pembelian. b) Uji Parsial (Uji t)

Pengujian ini dilakukan secara parsial yang dilakukan untuk menentukan diterima atau ditolaknya hipotesis. Pengujian hipotesis dilakukan untuk mengetahui apakah variabel promosi dan citra merek yang diuji berpengaruh terhadap keputusan pembelian. Jika $t_{\text {hitung }}>t_{\text {tabel }}$ atau signifikansi $\leq 0,05$, maka $\mathrm{H}_{0}$ ditolak.

Tabel 5

Perkiraan Nilai thitung

\begin{tabular}{|c|c|c|}
\hline & \multicolumn{2}{|c|}{ Coefficients $^{a}$} \\
\hline Model & $\mathbf{t}$ & Sig. \\
\hline $\begin{array}{ll} & \text { (Constant) } \\
1 & \text { PROMOSI } \\
& \text { CITRA_MER } \\
& \text { EK }\end{array}$ & $\begin{array}{l}4.457 \\
\mathbf{4 . 0 4 9} \\
\mathbf{7 . 4 7 6}\end{array}$ & $\begin{array}{l}.000 \\
.000 \\
.000\end{array}$ \\
\hline
\end{tabular}

a. Dependent Variable: KEP_PEMBELIAN

Sumber: data primer hasil pengolahan SPSS Versi 23 tahun 2017.

Berdasarkan tabel 5 diperoleh nilai $t_{\text {hitung }}$ pada variable promosi sebesar 4,049 $>\mathrm{t}_{\text {tabel }}$ dengan $\mathrm{df}=\mathrm{n}-\mathrm{k}-1 \quad(189-2-1=186)$ sebesar 1,972 atau taraf signifikan $0,000<\alpha 0,05$ maka $\mathrm{H}_{\mathrm{o}}$ ditolak, artinya promosi berpengaruh positif dan signifikan terhadap keputusan pembelian rokok A Mild yang ditawarkan oleh PT Duta Media Indonesia Area Pematangsiantar.

Sedangkan hasil tabel di atas didapat $t_{\text {hitung }}$ pada variable citra merek 7,476 $>t_{\text {tabel }}$ dengan $\mathrm{df}=\mathrm{n}$ - 
$\mathrm{k}-1, \quad(189-2-1=186)$ sebesar 1,987 atau taraf signifikan $0,000<\alpha 0,05$ maka Ho ditolak, artinya citra merek berpengaruh positif dan signifikan terhadap keputusan pembelian rokok A Mild yang ditawarkan oleh PT Duta Media Indonesia Area Pematangsiantar.

\section{Evaluasi}

a. Promosi rokok A Mild yang ditawarkan oleh PT Duta Media Indonesia Area Pematangsintar

Promosi merupakan hal yang penting yang perlu ditingkatkan oleh setiap perusahaan. Promosi merupakan suatu bentuk komunikasi antara perusahaan dengan konsumen untuk menyebarkan informasi dan mempengaruhi konsumen agar bersedia membeli dan loyal pada produk yang ditawarkan. Promosi yang baik akan membantu perusahaan dalam meningkatkan penjualan dan keuntungan.

PT Duta Media Indonesia Area Pematangsiantar melakukan promosi langsung kepada konsumen secara door to door sehingga konsumen dapat dengan mudah mendapatkan informasi dari brand presenter mengenai produk yang ditawarkan. Promosi yang dilakukan berdasarkan 4 dimensi yaitu periklanan, hubungan masyarakat, penjualan personal dan pemasaran langsung.

Berdasarkan hasil rekapitulasi yang diperoleh, maka diperoleh hasil penelitian yang menyatakan bahwa promosi rokok A Mild memperoleh nilai rata-rata keseluruhan sebesar 3,84 dengan kriteria jawaban baik. Sedangkan nilai ratarata tertinggi sebesar 4,05 dengan kriteria jawaban baik pada tiga indikator, yaitu pada dimensi periklanan untuk indikator kejelasan informasi rokok A Mild melalui brosur dan kejelasan informasi rokok A Mild melalui iklan televisi, dan pada dimensi hubungan masyarakat untuk acara yang diselenggarakan oleh rokok A Mild.

Namun dari hasil rekapitulasi penyebaran kuesioner masih ada beberapa indikator di dimensi lain yang perlu diperhatikan karena masih di bawah nilai rata-rata yaitu pada dimensi penjualan personal untuk indikator komunikasi brand presenter saat menawarkan produk rokok A Mild diperoleh nilai rata-rata sebesar 3,32 dengan kriteria jawaban cukup baik, hal ini dapat ditingkatkan dengan cara melatih komunikasi brand presenter sebelum melakukan penjualan agar terjalinnya komunikasi yang baik antara brand presenter dengan konsumen. Pada indikator kesopanan brand presenter saat menawarkan rokok A Mild diperoleh nilai rata-rata sebesar 3,83 dengan kriteria jawaban baik, hal ini dapat ditingkatkan dengan cara memberikan senyuman dan sikap ramah kepada konsumen, seperti menyambut dengan kata selamat pagi/siang/sore/malam sebelum melakukan penawaran rokok A Mild dan sebelum melakukan penawaran ada baiknya menanyakan orang yang kita tawarkan apakah seorang perokok atau tidak.
Pada indikator presentasi brand presenter dalam menawarkan rokok A Mild diperoleh nilai rata-rata sebesar 3,29 dengan kriteria jawaban cukup baik, hal ini dapat ditingkatkan lagi dengan cara melakukan pelatihan presentasi penjualan setiap sebelum melakukan penjualan, presentasi tersebut mengenai rasa, kandungan, dan harga pada rokok A Mild, jika presentasi yang dilakukan brand presenter sudah baik maka konsumen akan memahami presentasi brand presenter mengenai rasa, kandungan yang dimiliki dari rokok A Mild tersebut.

Dimensi pemasaran langsung untuk indikator keahlian brand presenter dalam membujuk untuk membeli rokok A Mild diperoleh nilai rata-rata sebesar 3,79 dengan kriteria jawaban baik, hal ini dapat ditingkatkan dengan cara melakukan presentasi yang baik agar meransang konsumen untuk membeli rokok A Mild.

\section{b. Citra Merek rokok A Mild yang ditawarkan oleh PT Duta Media Indonesia Area Pematangsintar}

Citra Merek (Brand Image) merupakan representasi dari keseluruhan persepsi terhadap merek dan dibentuk dari informasi dan pengalaman masa lalu terhadap merek itu. Citra terhadap merek berhubungan dengan sikap yang berupa keyakinan dan berupa preferensi terhadap suatu merek. Konsumen yang memiliki citra yang positif terhadap suatu merek, akan lebih meningkatkan untuk melakukan pembelian.

Berdasarkan hasil rekapitulasi, maka diperoleh hasil penelitian yang yang menyatakan bahwa citra merek rokok A Mild memperoleh nilai rata-rata keseluruhan sebesar 3,72 dengan kriteria jawaban baik. Sedangkan nilai rata-rata tertinggi sebesar 3,86 dengan kriteria jawaban baik pada dimensi kekuatan merek dengan indikator rasa pada produk rokok A Mild. Namun dari hasil rekapitulasi penyebaran kuesioner masih ada beberapa indikator di dimensi lain yang perlu diperhatikan karena masih di bawah nilai rata-rata yaitu pada dimensi keunggulan merek untuk indikator kualitas pada produk rokok A Mild diperoleh nilai rata-rata sebesar 3,64 dengan kriteria jawaban baik, hal ini dapat ditingkatkan dengan cara melakukan promosi secara terus menerus agar merek cepat diketahui oleh konsumen dan bisa meningkatkan keunggulan merek, seperti melakukan promosi melalui televisi, koran atau bahkan media sosial yang banyak digunakan pembisnis untuk melakukan promosi.

Pada indikator ciri khas produk rokok A Mild diperoleh nilai rata-rata sebesar 3,57, hal ini dapat diatasi dengan cara memperhatikan memperhatikan kemasan produk, karena keunikan dari sebuah produk yang pertama kali diperhatikan konsumen adalah tampilan kemasan seperti bungkus karton yang besar tipis, bungkus karton kecil dan bungkus kaleng.

Dimensi keunikan merek untuk indikator desain pada rokok A diperoleh nilai rata-rata sebesar 3,71 dengan kriteria jawaban baik, hal ini dapat 
ditingkatkan dengan cara melakukan inovasi terhadap rokok A Mild agar meningkatkan keunikan merek, seperti membuat desain terbaru pada rokok A Mild yaitu bungkus yang berwarna warni atau bungkus yang lebih mewah yang dapat membangun keunikan dari merek A Mild.

Selanjutnya pada indikator nama merek rokok A Mild memiliki nilai rata-rata sebesar 3,61 dengan kriteria jawaban baik, hal ini dapat ditingkatkan dengan cara menciptakan nama produk yang baru seperti A Mild Bentoel, A Mild coklat atau nama lain sesuai rasa dari produk tersebut yang selain rokok putih. Pada indikator logo merek rokok A Mild diperoleh nilai rata-rata sebesar 3,67 dengan kriteria jawaban baik, hal ini dapat ditingkatkan dengan cara menciptakan pesan-pesan yang unik, karena logo bukanlah hanya sekedar bentuk tetapi juga ada arti dibalik logo tersebut, seperti logo rokok A Mild memiliki banyak pesan-pesan unik yaitu go Ahead (lanjutkan) yang artinya konsumen tetap melanjutkan untuk mengkonsumsi rokok A Mild.

\section{c. Keputusan Pembelian rokok A Mild yang ditawarkan oleh PT Duta Media Indonesia Area Pematangsintar}

Keputusan pembelian merupakan tindakan yang dilakukan konsumen untuk membeli suatu produk, dimana pada dasarnya pengambilan keputusan pembelian setiap orang sama, dalam proses dalam pengambilan keputusan pembelian pasti berbeda-beda, seperti kepribadian, gaya hidup, usia, penghasilan dan lain-lain. Dimensi keputusan pembelian meliputi pengenalan masalah, evaluasi alternatif, keputusan pembelian dan perilaku setelah pembelian.

Berdasarkan hasil rekapitulasi yang diperoleh, maka diperoleh hasil penelitian yang menyatakan bahwa keputusan pembelian rokok A Mild memperoleh nilai rata-rata sebesar 3,63 dengan kriteria jawaban baik. Sedangkan nilai rata-rata tertinggi sebesar 3,93 dengan kriteria jawaban baik pada dimensi pencarian informasi untuk indikator keakuratan informasi produk rokok A Mild. Namun tentunya ada beberapa indikator di dimensi lain yang perlu diperhatikan karena masih di bawah nilai ratarata. Nilai terendah yang pertama yaitu pada dimensi pencarian informasi untuk indikator cara brand presenter mengenalkan produk rokok A Mild diperoleh nilai rata-rata sebesar 3,55 dengan kriteria jawaban baik, hal ini dapat diatasi dengan cara meningkatkan presentasi yang dilakukan brand presenter agar lebih jelas untuk memberitahu informasi rokok A Mild dan dapat diingat oleh konsumen.

Dimensi evaluasi alternatif untuk indikator keyakinan dalam mengkonsumsi produk Rokok A Mild 3,57 dengan kriteria jawaban baik, hal ini dapat ditingkatkan dengan cara brand presenter PT Duta Media Indonesia Area Pematangsiantar memberikan sampel kepada konsumen agar mereka yakin bahwa rasa rokok A Mild sesuai dengan harapan konsumen dan mereka akan yakin dalam mengkonsumsi rokok A Mild. Pada dimensi keputusan pembelian untuk indikator minat pada rokok A Mild diperoleh nilai rata-rata sebesar 3,19 dengan kriteria jawaban cukup baik, hal ini dapat diatasi dengan cara membujuk konsumen agar berminat membeli rokok A Mild seperti memberitahu kembali cita rasa yang dimiliki rokok A Mild, keunggulan rokok A Mild dibandingkan rokok lain.

Dimensi evaluasi setelah pembelian untuk indikator kesesuaian kinerja rokok A Mild dengan harapan diperoleh nilai rata-rata sebesar 3,55 dengan kriteria jawaban baik, hal ini dapat ditingkatkan lagi dengan cara memperbaiki informasi yang diberikan brand presenter kepada konsumen agar konsumen mengetahui kinerja rokok A Mild apakah sesuai informasi yang diberikan brand presenter atau tidak. Untuk indikator sikap melakukan pembelian kembali rokok A Mild diperoleh nilai rata-rata sebesar 3,14 dengan kriteria jawaban cukup baik, hal ini dapat diatasi dengan selalu selalu mengingatkan konsumen setiap selesai melakukan penawaran rokok A Mild untuk tetap setia pada produknya, seperti jangan lupa untuk tetap setia dalam mengkonsumsi rokok A Mild yang memiliki kualitas baik.

\section{KESIMPULAN DAN SARAN}

\section{Kesimpulan}

a. Hasil analisis deskriptif kualitatif tentang promosi rokok A Mild yang ditawarkan oleh PT Duta Media Indonesia Area Pematangsiantar memiliki nilai keseluruhan 3,73 dan dinilai baik. Dari rata-rata tersebut diperoleh nilai tertinggi yaitu 4,05 pada dimensi periklanan dan hubungan masyarakat. Nilai terendah yaitu 3,29 pada kategori presentasi brand presenter.

b. Hasil analisis deskriptif kualitatif tentang citra merek rokok A Mild yang ditawarkan oleh PT Duta Media Indonesia Area Pematangsiantar memiliki nilai keseluruhan 3,72. Dari rata-rata tersebut diperoleh nilai tertinggi yaitu 3,86 pada kategori rasa produk rokok A Mild, sedangkan untuk nilai terendah yaitu 3,57 pada kategori ciri khas produk rokok A Mild.

c. Hasil analisis deskriptif kualitatif tentang keputusan pembelian rokok A Mild memiliki nilai keseluruhan 3,63. Dari rata-rata tersebut diperoleh nilai tertinggi yaitu 3,93 pada kategori alokasi keakuratan informasi rokok A Mild. Nilai terendah yaitu 3,14 pada kategori sikap melakukan pembelian kembali rokok A Mild.

d. Hasil analisis regresi $\hat{Y}=15,181+0,297 \mathrm{X}_{1}+$ $0,765 \mathrm{X}_{2}$, artinya terdapat pengaruh yang positif antara promosi dan citra merek terhadap keputusan pembelian rokok A Mild yang ditawarkan oleh PT Duta Media Indonesia Area Pematangsiantar.

e. Hasil nilai korelasi menunjukkan bahwa terdapat hubungan baik dan positif yaitu sebesar 0,653 antara variabel promosi dan citra merek terhadap keputusan pembelian rokok A Mild yang ditawarkan oleh PT Duta Media Indonesia Area Pematangsiantar sesuai dengan 
kriteria koefisien korelasi pada tabel 5 . Kemudian diperoleh nilai koefisien determinasi yaitu 0,427 , artinya baik tidaknya keputusan pembelian dijelaskan sebesar $42,7 \%$ oleh promosi dan citra merek selebihnya 57,3\% dijelaskan oleh faktor lain seperti situasional, lingkungan dan sosial budaya konsumen.

f. Hasil pengujian $F_{\text {hitung }}$ sebesar 69,284 > $F_{\text {tabel }}$ pada tingkat $(0,05,2$ vs $(189-2-1))$ adalah sebesar 3,04. Oleh karena $F_{\text {hitung }}>F_{\text {tabel }}$ atau taraf signifikansi $0,000<$ dari $\alpha 0,05$, maka $\mathrm{H}_{\mathrm{o}}$ ditolak, artinya promosi dan citra merek berpengaruh positif dan signifikan terhadap keputusan pembelian rokok A Mild yang ditawarkan oleh PT Duta Media Indonesia Area Pematangsiantar secara simultan

g. Hasil pengujian didapat variabel promosi didapat $\mathrm{t}_{\text {hitung }}$ sebesar 4,049 $>\mathrm{t}_{\text {tabel }}$ sebesar 1,972 atau taraf siginifikan $0,000<$ dari $\alpha 0,05$ maka $\mathrm{H}_{\mathrm{o}}$ ditolak, artinya promosi berpengaruh positif dan signifikan terhadap keputusan pembelian rokok A Mild yang ditawarkan oleh PT Duta Media Indonesia Area Pematangsiantar dan variabel citra merek didapat $t_{\text {hitung }} 7,476>t_{\text {tabel }}$ sebesar 1,972 atau taraf signifikan $0,000<$ dari $\alpha$ 0,05 maka $\mathrm{H}_{\mathrm{o}}$ ditolak, artinya citra merek berpengaruh positif dan signifikan terhadap keputusan pembelian rokok A Mild yang ditawarkan oleh PT Duta Media Indonesia Area Pematangsiantar.

\section{Saran}

a. Promosi rokok A Mild yang ditawarkan oleh PT Duta Media Indonesia Area Pematangsiantar sudah baik, tetapi masih terdapat beberapa indikator yang rendah. Untuk meningkatkan dan memperbaikinya sebaiknya promosi rokok A Mild lebih ditingkatkan, terutama pada penjualan personal harus memiliki komunikasi dan presentasi yang baik kepada konsumen sehingga meningkatkan efektivitas komunikasi dan presentasi penjualan personal.

b. Citra merek rokok A Mild yang ditawarkan oleh PT Duta Media Indonesia Area Pematangsiantar sudah baik. Untuk meningkatkan dan memperbaikinya sebaiknya promosi rokok A Mild lebih ditingkatkan lagi agar citra merek rokok A Mild lebih dikenal baik oleh masyarakat indonesia.

c. Keputusan pembelian rokok A Mild yang ditawarkan oleh PT Duta Media Indonesia Area Pematangsiantar sudah baik, tetapi masih terdapat beberapa indikator yang rendah. Untuk meningkatkan dan memperbaikinya sebaiknya PT Duta Media Indonesia Area Pematangsiantar memberikan informasi yang jelas dan sesuai terhadap kualitas dan rasa pada produk sehingga dapat menimbulkan daya rangsang yang positif bagi setiap konsumen untuk melakukan pembelian.

d. Sehubungan dengan keterbatasan pada penulis, penelitian ini masih banyak terdapat kelemahan dan belum dapat mengungkapkan seluruh variabel yang dapat mempengaruhi keputusan pembelian rokok A Mild yang ditawarkan oleh PT Duta Media Indonesia Area Pematangsiantar. Sebagai bahan penelitian selanjutnya, perlu memperbanyak variabel seperti kualitas produk, harga, dan kepuasan yang tidak dibahas dalam penelitian ini.

\section{E. DAFTAR PUSTAKA}

Adirama, A. 2012. Pengaruh Citra Merek dan Kualitas Produk Terhadap Keputusan Pembelian Konsumen ( Studi Kasus pada Konsumen Sepeda Motor Satria FU di Kelaten). Kelaten: Universitas Negeri Yogyakarta. Skripsi.

Alfian. 2012. Pengaruh Citra Merek (Brand Image) Terhadap Pengambilan Keputusan Pembelian Mobil Toyota Kijang Innova pada PT Hadji Kalla cabang polman. Makassar: Universitas Hasanuddin. Skripsi.

Anggar, K. 2012. Analisis Pengaruh Harga, Kualitas Produk dan Promosi Terhadap Keputusan Pembelian Sepeda Motor Honda (Studi kasus pada Konsumen di Kota Semarang). Semarang: Universitas diponegoro. Skripsi.

Mowen, John. C dan Michael Minor. 2000. Perilaku Konsumen. Jilid 1. Jakarta:Binarupa Aksara

Boyd, et. al. 2000. Manajemen Pemasaran : Suatu Pendekatan Strategis dengan Orientasi Global. Edisi II. Jilid 1. Jakarta: Erlangga.

Daft, Richard L. 2002. Manajemen. Jakarta: Salemba Empat.

2006. Manajemen. Jilid 1, Edisi 5. Jakarta: Erlangga.

Davis, Keith \& John W. Newstrom. 2000. Perilaku Dalam Organisasi. Edisi ketujuh. Jakarta: Erlangga.

Ferrinadewi, Erna. 2008. Merek dan Psikologi Konsumen. Edisi 1. Yogyakarta: Graha Ilmu.

Ghozali, Imam. 2016. Aplikasi Analisis Multivarite dengan IBM SPSS 23, Edisi Kedelapan. Semarang. Badan Penerbit Universitas Diponegoro.

2005. Aplikasi Analisis Multivarite dengan Program SPSS. Semarang: Penerbit Universitas Diponegoro

Griffin, Ricky W. 2004. Manajemen. Edisi VII, Jilid 1. Jakarta: Erlangga.

Hasan, Ali. 2013. Marketing dan Kasus-kasus Pilihan. Jakarta: Center For Academic Publicing Service (CASP).

Irawan, P.D. 2014. Pengaruh Strategi Promosi Terhadap Keputusan Pembelian Yang Dimediasi Oleh Minat Beli Pada Konsumen Matahari Departement Store Yogyakarta. Yogyakarta: Universitas Negeri Yogyajarta. Skripsi. 
Kotler, Philip \& Gary Armstrong. 2008. PrinsipPrinsip Pemasaran. Edisi 12. Jilid 1. Jakarta: PT Indeks.

Kotler, Philip dan Gary Amstrong. 2012. Prinsipprinsip Pemasaran. Edisi 13. Jilid 1. Jakarta: Penerbit Erlangga.

Kotler, Philip \& Kevin Lane Keller. 2008. Manajemen Pemasaran. Edisi 12. Jilid 1. PT. Jakarta: PT. Indeks.

Kotler, Philip \& Kevin Lane Keller. 2009. Manajemen Pemasaran. Edisi 12. Jilid 1. Jakarta: PT Gelora Aksara Pratama.

Laheba, Y.A., Tumbuan, W.J.F.A., Soepeno, D 2015. Pengaruh Citra Merek, Fitur dan Harga Terhadap Keputusan Pembelian Handphone Samsung (Studi pada Mahasiswa FEB Unsrat Manado). Manado: Universitas Sam Ratulangi Manado. Jurnal EMBA. Volume 3, Nomor 3 ,

https://media.neliti.com/media/publications/ 2676-ID-pengaruh-citra-merek-fitur-danharga-terhadap-keputusan-pembelianhandphone-sams.pdf. 20 Juni 2017.

Lupiyoadi, Rambat dan Hamdani, A. 2006. Manajemen Pemasaran. Jakarta: Salemba empat.

Malik, M.E., Ghafoor, M.M., Iqbal. H.K. 2012. Impact of Brand Image, Service Quality and Price on Customer Satisfaction in Pakistan Telecommunication Sector. Pakistan: University of The Punjab. Internasional Journal of Business and Social Science.Volume 3, Nomor 23, http://ijbssnet.com/journals/vol_3_No_23 December_2012/13.pdf. 20 Juni 2017

Prasetyo. 2007. feunsika.ac.id/Jurnal-online/wpcontent/.../DEDI-UUS-090412.pdf.
Undang-Undang Merek. Diakses tahun 2017

Rangkuti, Freddy. 2009. Mengukur Efektivitas Program Promosi dan Analisis Kasus Menggunakan SPSS. Jakarta: PT Gramedia Pustaka Utama.

Robbins, Stephen P dan Mary Coutler. 2011. Manajemen. Edisi X, Jilid 1. Indonesia: PT Gelora Aksara Pratama.

Setiadi, Nugroho J. 2003. Perilaku Konsumen, Konsep dan Implikasi untuk Strategi dan Penelitian Pemasaran. Jakarta : Prenada Media.

Setiadi, Nugroho. 2008. Perilaku Konsumen (Perspektif Kontemporer pada Motif, Tujuan dan keinginan Konsumen). Edisi I. Cetakan ke-3. Jakarta: Kencana.

Simamora, Bilson. 2004. Riset Pemasaran, falsafah, Teori dan Aplikasi. Jakarta: PT Gramedia Pustaka Utama.

Sugiyono. 2013. Metode Penelitian Kuantitatif Kualitatif R \& D. Cetakan ke 1 Bandung: Penerbit Alfabeta.

Sumarwan, Ujang. 2004. Perilaku Konsumen. Teori dan Penerapannya dalam Pemasaran. Jakarta: Ghalia Indonesia.

Sutisna dan Prawitra. 2001. Perilaku Konsumen dan Komunikasi Pemasaran. Jakarta : PT. Remaja Rosda Karya.

Swastha, Basu \& Irawan. 2005. Manajemen Pemasaran Modern. Yogyakarta: Liberty.

Tjiptono, Fandy dan Gregorius Chandra. 2011. Service, Quality \& Satisfaction. Yogyakarta: Andi.

Tjiptono, Fandy. 2008. Strategi Pemasaran. Yogyakarta: Andi. 